ROCZNIKI HISTORYCZNE

Rocznik LXXXII — 2016

ADAM SZWEDA (Uniwersytet Mikołaja Kopernika, Toruń)

\title{
Starania Jana Olbrachta o krzyżacką pomoc przeciwko księciu mazowieckiemu Konradowi III Rudemu w 1495 roku
}

Zarys treści: Artykuł opisuje żądania Jana Olbrachta, aby wielki mistrz Jan von Tiefen i Zakon Krzyżacki udzielili mu pomocy przeciwko księciu Konradowi Rudemu, który nieprawnie zajął księstwo płockie. Krzyżacy nie kwestionowali ich zasadności, ale grali na zwłokę, proponując najpierw mediację. Do akcji zbrojnej nie doszło, ponieważ król rozstrzygnął spór z Konradem we własnym zakresie.

Content outline: The paper describes the requests of Jan Olbracht to the Grand Master Johann von Tiefen and the Teutonic Order for help against Duke Konrad the Red, who illegally took over the Duchy of Płock. The Teutonic Knight did not question its validity, but temporised, suggesting their mediation first. No military action followed, as the king solved the argument with Konrad himself.

Słowa kluczowe: Mazowsze, Zakon Krzyżacki, król Jan Olbracht, II pokój toruński, prawo lenne Keywords: Masovia, Teutonic Order, king Jan Olbracht, Second Peace of Toruń, feudal law

Drugi pokój toruński z 19 X 1466 r. gruntownie zmieniał dotychczasowe relacje prawne pomiędzy Polską a Zakonem Krzyżackim (Niemieckim). Wielki mistrz stawał się radcą króla i Korony, zobowiązanym do składania przysięgi wierności ${ }^{1}$. W jednym z artykułów traktatu wielki mistrz Ludwik von Erlichshausen stwierdzał, że on i jego następcy są zobowiązani wspierać Kazimierza Jagiellończyka i jego następców oraz Królestwo Polski przeciwko wszelkim wrogom, podobnie jak inni prałaci, książęta i dostojnicy Królestwa, consiliis, auxiliis et suffragiis oportunis ${ }^{2}$. Cztery dni później król zwolnił swojego nowego radcę od obowiązku pomocy zbrojnej na 20 lat z powodu zniszczenia kraju w wyniku długotrwałej wojny, niemniej z wyjątkiem walki z zagrożeniem tureckim ${ }^{3}$. Długie lata nie było sposobności sprawdzić, jak wygląda realizacja przytoczonej wyżej regulacji. Dopiero w 1485 r. król zwrócił się do Krzyżaków o pomoc w walce z Turkami. Choć z oporami, wielki mistrz Marcin Truchsess zgodził się jednak na jej udzielenie, ale od czynnego wystąpienia zwolniła go

${ }^{1}$ A. S z we d a, Princeps et consiliarius Regni Poloniae. Król i wielki mistrz w latach 1466-1497, w: Od traktatu kaliskiego do pokoju oliwskiego. Polsko-krzyżacko-pruskie stosunki dyplomatyczne w latach 1343-1660, Warszawa 2014, s. 241-245, gdzie starsza literatura.

${ }^{2}$ Die Staatsverträge des Deutschen Ordens in Preußen im 15. Jahrhundert, t. II, wyd.

E. Weise, Marburg 1955, nr 403, s. $275 \S 6$ (4).

3 Tamże, nr 407. 
zmiana sytuacji politycznej4. Do kolejnej sytuacji, kiedy wsparcie militarne Zakonu dla Polski stało się kwestią aktualną, doszło w 1495 r., w związku ze sprawą inkorporacji Mazowsza do Korony.

Batalia o włączenie księstwa płockiego do Polski rozpoczęła się, kiedy w nocy z 26 na 27 II 1462 r. zmarł ostatni przedstawiciel zachodniomazowieckiej linii Piastów - Włodzisław (Władysław) II ${ }^{5}$. Do objęcia spadku po nim zgłosił się jego suweren król Kazimierz Jagiellończyk. Władca konsekwentnie dążył do wcielenia księstwa płockiego do Korony ${ }^{6}$. Zadbał w tym celu m.in. o powołanie sądu złożonego ze swoich poddanych (wojewody kaliskiego Stanisława z Ostroroga jako sędziego, podkomorzego lubelskiego Grota z Ostrowa jako podsędka oraz członków rady królewskiej jako asesorów), którego orzeczenia stały się podstawą inkorporacji ziemi bełskiej, rawskiej i gostynińskiej już w 1462 r. ${ }^{7}$ W Płocku jednak władzę przejął Konrad III Rudy z linii wschodniomazowieckiej i utrzymał się mimo kilkuletniej walki prawnej, a nawet po wyroku sądu królewskiego z 22 X 1468 r. (w takim samym składzie, jak sześć lat wcześniej), który odsądzał księcia od posiadania ziemi płockiej i innych ziem podległych dotąd wygasłej gałęzi dynastii ${ }^{8}$. W $1471 \mathrm{r}$. w wyniku podziału dokonanego pomiędzy synami Bolesława IV Płock przypadł Kazimierzowi III, a gdy ten został konsekrowany w 1475 r. na biskupa płockiego, sprzedał ziemie płocką, wiską i zawkrzeńską młodszemu bratu, Januszowi II ${ }^{9}$. Nagła śmierć tego ostatniego 16 II 1495 r. ${ }^{10}$ stworzyła nową sytuację, ponieważ o prawa Korony do przysądzonych wcześniej ziem upomniał się król Jan Olbracht, który nabytkami na Mazowszu zainteresowany był od początków swoich rządów ${ }^{11}$. Konrad III (jego pozycja w relacjach z Koroną była niekorzystna, gdyż to jemu personalnie wyrok sądu z 1468 r. odmawiał praw do księstwa płockiego), podjął szybką akcję, zajmując władztwo swego starszego brata już w marcu 1495 r. ${ }^{12}$ Polski monarcha działał stosunkowo nieśpiesznie, zwołując pospolite ruszenie z Kujaw, ziemi dobrzyńskiej oraz z ziemi rawskiej na 10 sierpnia $^{13}$. Jednocześnie prowadził bezpośrednie rozmowy z Konradem, ograniczając się zresztą do wywierania na nim dość bezceremonialnej presji ${ }^{14}$.

${ }^{4}$ A. S z w e d a, Princeps, s. 250, 254-255.

5 K. J a s i ń s ki, Rodowód Piastów mazowieckich, Poznań-Wrocław 1998 [recte: 2008], s. 153-154; J. G r a b o w s k i, Dynastia Piastów mazowieckich. Studia nad dziejami politycznymi Mazowsza, intytulacją i genealogią książąt, Kraków 2012, s. 131.

${ }^{6}$ Mazowiecką politykę Kazimierza Jagiellończyka szczegółowo omawia P. W ę c o w s k i, Mazowsze w Koronie. Propaganda i legitymizacja władzy Kazimierza Jagiellończyka na Mazowszu, Kraków 2004.

7 Tamże, s. 49-51; por. A. Sw i ė a w s k i, Wcielenie ziemi rawskiej, gostynińskiej i bełskiej do Korony (1462), Zeszyty Naukowe UŁ, Nauki Humanistyczno-Społeczne, seria I, z. 27, 1962 (przedruk w: tenże, Mazowsze i Ruś Czerwona w średniowieczu. Wybór pism, Częstochowa 1997, s. 7-16); J. Gr a b o w s k i, Dynastia, s. 134-139.

${ }^{8}$ P. W ę c ow s ki, Mazowsze, s. 55-67; J. Gra b ow s ki, Dynastia, s. 139.

${ }^{9}$ P. W ę c ow sk i, Mazowsze, s. 68-70; J. Grab o w s ki, Dynastia, s. 177-180.

${ }^{10}$ K. J a s ińs ki, Rodowód, s. 188; J. Gra b ow sk i, Dynastia, s. 493.

${ }^{11}$ F. P a pé e, Jan Olbracht, Kraków 2006 (wyd. 1: 1936), s. 88-90.

12 Tamże, s. 91.

13 Tamże.

14 Atmosferę tych i późniejszych rozmów znakomicie oddają spisane z inicjatywy mazowieckiej instrumenty notarialne relacjonujące ich przebieg (J. T ę g o w s k i, Odłączenie ziemi 
Na etapie gromadzenia środków przymusu bezpośredniego król postanowił odwołać się także do pomocy wielkiego mistrza Jana (Hansa) von Tiefena ${ }^{15}$. Ich wzajemne relacje miały już swoją historię. Mistrz po swoim wyborze 1 IX 1489 r. złożył przewidzianą II pokojem toruńskim przysięgę wierności królowi Kazimierzowi Jagiellończykowi $\mathrm{w}$ listopadzie tr. na sejmie w Radomiu ${ }^{16}$. Niespełna trzy lata później Tiefen, mimo nalegań ze strony polskiej, nie zdecydował się na aktywne wzięcie udziału w elekcji następcy Kazimierza Jagiellończyka, co nie wpłynęło na polepszenie jego stosunków ze zwycięskim Janem Olbrachtem ${ }^{17}$. Władca ten zażądał od mistrza złożenia nowej przysięgi, co wzbudziło sprzeciw strony zakonnej, skoro Jan von Tiefen składał już takową Kazimierzowi Jagiellończykowi. W sytuacji, kiedy nie udało się uniknąć tego aktu, Krzyżakom zależało na tym, aby również nowy król zaprzysiągł traktat pokojowy jako układ dwustronny. Dokonał tego uroczyście - według świadectw dziejopisarskich - Kazimierz Jagiellończyk 19 X 1466 r. ${ }^{18}$ Obowiązek przysięgi królewskiej nie był jednak - w odróżnieniu od przysięgi wielkiego mistrza - wpisany w układ pokojowy (fakt ten Klaus Neitmann uznał ostatnio za najbardziej dobitny dowód na nierówny charakter II pokoju toruńskiego ${ }^{19}$ ), zatem Jan Olbracht uchylił się od takiej czynności, składając tylko obietnicę przestrzegania pokoju w rozmowie z Janem von Tiefenem. Wielki mistrz musiał natomiast dopełnić całego ceremoniału ${ }^{20}$. Syn Kazimierza Jagiellończyka zdecydowany był kontynuować dość zdecydowaną politykę swego ojca wobec Zakonu Krzyżackiego. Ten ostrzejszy kurs zapoczątkowany został podczas ogólnopruskiego zjazdu w Toruniu w $1485 \mathrm{r}^{21}$

Przebieg starań Jana Olbrachta o pomoc przeciwko Konradowi Rudemu oraz krzyżackie stanowisko w tej sprawie są nam znane z relacji wpisanej do zakonnej księgi kancelaryjnej (Ordensfoliant), przechowywanej obecnie wraz z resztą archiwum wielkiego mistrza w Berlinie ${ }^{22}$. Foliant ten swoją obecną postać uzyskał dopiero w XIX w., ale zawiera znaczną część wcześniejszej księgi znanej jako

płockiej od Mazowsza w latach 1495-1496 (przyczynek źródłowy), w: Stilo et animo. Prace historyczne ofiarowane Profesorowi Tomaszowi Jasińskiemu w 65. rocznicę urodzin, Poznań 2016, s. 389-398).

${ }^{15}$ Dotąd o fakcie tym napomknął jedynie L. D r a 11 e, Der Staat des Deutschen Ordens in Preußen nach dem 2. Thorner Frieden, Wiesbaden 1975, s. 149.

16 A. S z w e d a, Princeps, s. 255.

17 Tamże, s 255-256.

18 Ostatnio S. J óź w i a k, Sposoby zaprzysięgania polsko-krzyżackich traktatów pokojowych w XV w. na tle zachodnioeuropejskich procedur ratyfikacyjnych, w: Torun miastem pokoju. II pokój toruński, Toruń 2016, s. 135-136 (tu źródła); por. M. B i s k u p, Trzynastoletnia wojna z Zakonem Krzyżackim 1454-1466, Warszawa 1967, s. 709-710; A. S z w e d a, Princeps, s. 242.

${ }^{19}$ K. N e it $\mathrm{m}$ a n n, Von der Herstellung und Sicherung des „ewigen Friedes”. Der II. Thorner Friede von 1466 im Rahmen der Landfriedensvereibarungen und Friedenschlüsse des Deutschen Ordens in Preußen mit seinen Nachbarmächten im 15. Jahrhundert, w: Erbeinungen und Erbverbrüderungen in Spätmittelalter und Früher Neuzeit. Generationsübergreifende Verträge und Strategien im europäischen Vergleich, Berlin 2014, s. 210.

${ }^{20}$ A. S z w e d a, Princeps, s. 256-257; K. N e it $\mathrm{m}$ a n n, Von der Herstellung, s. 206.

${ }^{21}$ A. S zw e d a, Princeps, s. 250-255.

${ }^{22}$ Berlin-Dahlem, Geheimes Staatsarchiv Preußischer Kulturbesitz, XX. HA, OF $18 \mathrm{c}$ (dalej cyt.: OF 18c). 
„Registrant B”, a gromadzącej wpisy związane głównie z relacjami polsko-krzyżackimi. Retrospektywnie obejmował on sprawy od 1412, a prowadzony był do $1497 \mathrm{r}^{23}$ Interesujący nas fragment powstał zatem współcześnie, w obrębie księgi stanowi zaś wyodrębnioną całość.

Poseł królewski, kanonik chełmiński Jan Konopacki ${ }^{24}$, stawił się przed wielkim mistrzem 1 VIII 1495 r. w zakonnym zamku w Szakach (niem. Schaaken, obecnie Niekrasowo w obwodzie kaliningradzkim), okazał swoją kredytywę i przedstawił stan rzeczy z punktu widzenia swego mocodawcy. Zgodnie z nim po śmierci Janusza II pozostałe po nim „land, stete und geslos” przypadły królowi i Koronie „erblich - - nicht ane redlich ursach und zusproch". Teraz jednak Jan Olbracht bezskutecznie domaga się wydania tych posiadłości od Konrada, również rozmowy z mazowieckim księciem nie dały efektu. W tej sytuacji król, skoro prawo było po jego stronie, zdecydował się wezwać wielkiego mistrza „nach lawte und inhalt des ewigen friedes" do poczynienia odpowiednich przygotowań, ponieważ on sam i cały Zakon winni są królowi „beistandt, - - rath und hulffe"25. Poza kredytywą i swoim słowem Konopacki jako dowód królewskich praw do Mazowsza płockiego i innej spuścizny po Januszu II okazał też dokument (oryginał lub odpis) Jana Olbrachta wystawiony 10 VII 1495 r. w Rawie, ponieważ jego treść również została wpisana do krzyżackiego foliantu. Był to uniwersał zwołujący pospolite ruszenie z ziemi dobrzyńskiej do Lipna na 10 sierpnia, prezentujący jednocześnie historię sporu i królewskie prawa do księstwa płockiego ${ }^{26}$.

Jan Konopacki odpowiedź na swoje poselstwo uzyskał następnego dnia. Po odbyciu narady w wąskim gronie doradców wielki mistrz doszedł do wniosku, że nie może przekazać wiążącej i pełnej odpowiedzi bez zasięgnięcia opinii „biskupów, prałatów, urzędników, rycerstwa oraz miast”. Reprezentanci pruskich stanów mieli się stawić u zwierzchnika zakonu krótko po Wniebowzięciu NMP (15 sierpnia) i dopiero po tym zjeździe miało się udać do króla krzyżackie poselstwo z odpowiedzią 27 . Zapowiedziany tu zjazd w reakcji na misję kanonika Jana Konopackiego został zwołany do Bartoszyc (niem. Bartenstein) na środę po Wniebowzięciu NMP, czyli na 18 VIII 1495 r. Z tego też dnia pochodzą pierwsze informacje o krzyżackiej reakcji na królewskie żądanie.

Zachowane $\mathrm{w}$ foliancie informacje $\mathrm{z}$ tym związane otwiera tekst spisany po łacinie, mający charakter ekspertyzy sporządzonej przez prawnika. Nie wiadomo, kto jest jej

${ }^{23}$ M. Thu m s e r, Schriftlichkeit in der Spätzeit der preußischen Deutschordensherrschaft. Kanzleitätigkeit und Aufzeichnungen des hochmeisterlichen Sekretärs Liborius Naker (+1502/1503), w: Schriftkultur und Landesgeschichte. Studien zum südlichen Ostseeraum vom 12. bis zum 16. Jahrhundert, Köln-Weimar-Wien 1997, s. 185-186.

${ }^{24}$ Późniejszy biskup chełmiński, w kancelarii królewskiej czynny już od 1491 r. Jego biogram opracował niedawno W. N o w o s a d, Konopaccy herbu Odwaga-dzieje pomorskiej rodziny senatorskiej w XV-XVIII wieku, Warszawa 2014, s. 49-57, który nie zna jednak omawianej misji, a fakt objęcia przez Jana kanonii chełmińskiej kładzie na „niewiele wcześniej niż kwiecień 1503" (s. 52), natomiast samo wstąpienie Konopackiego do stanu duchownego datuje na 1500 r. (s. 51).

${ }^{25}$ OF $18 \mathrm{c}, \mathrm{s} .105$.

26 Tamże, s. 107.

27 Tamże, s. 106. 
autorem. W ówczesnej kancelarii w Królewcu działały przynajmniej trzy osoby mające odpowiednie kompetencje i wykształcenie - kanclerz i kapelan wielkiego mistrza Michael Sculteti, najwyższy sekretarz Liborius Naker oraz sekretarz Albert Spirau ${ }^{28}$. $\mathrm{Na}$ początku zarysowano przedmiot sprawy: Hic neccesserunt certa consideranda puncta et dubia monenda, ex quo regia maiestas citare fecit magistrum generalem et vocare cum suis preceptoribus et subditis ad expedicionem contra dominum Conradum ducem Mazouie, qui terram Plocensem cum suis districtibus, que ex speciali decreto spiritualium atque secularium consiliariorum Regni regi Polonie olim defuncto et sue serenitatis legittimis heredibus et successoribus adiudicata perpetuoque Corone Polonie incorporata esse debeat ab antiquo etc., et alie terre [!] ducis Johannusii [!] post eius mortem ad suam serenitatem iure feodi devolute, regie maiestati moderno non intendit ad manus tradere nec iusticiam ex se ipso ministrare, ut magister generalis sue maiestati regie iuxta inscripcionem pacis perpetue consilium et auxilium prestet etc. Quid ad hoc respondendum sit aut in hac re faciendum ${ }^{29}$. Dalej prawnik wielkiego mistrza zajął się szczegółowymi kwestiami. Jeżeli chodzi o fakt przysądzenia ziemi płockiej i innych ziem Janusza II Królestwu na mocy prawa lennego (iure feudi), stwierdził, że Zakon nie może się do tego ustosunkować, ponieważ jego przedstawiciele ani nie widzieli sentencji wyroku, ani nie jest im znana podstawa prawna przejścia tych terytoriów (ius devolucionis) do Korony ${ }^{30}$. Te zastrzeżenia traciły jednak na znaczeniu w świetle dalszego wywodu jurysty: Sed secundo ponderandum est, an magister generalis regie maiestati licite et sine preiudicio pacis perpetue consilium et auxilium contra ducem Conradum, qui dictarum terrarum Mazouie legittimus existit heres, poterit denegare. Dico, quod iuxta tenorem articuli pacis perpetue magistrum generalem sine preiudicio illius pacis regie maiestati non posse denegare consilium et auxilium contra Conradum ducem Mazouie, sive rex habeat iustam, sive iniustam causam. Charakterystyczne jest stanowisko krzyżackie, uznające prawo Konrada do spornych ziem i de facto domniemające nieprawość pretensji królewskich, stwierdzające jednakowoż, że brzmienie regulacji II pokoju toruńskiego nie daje zwierzchnikowi Zakonu właściwie żadnego pola manewru. W powstałej sytuacji zakonny kancelista proponuje zacząć od udzielenia rady królowi. W jej myśl Jan Olbracht mógłby zgodzić się, aby sporne terytoria trzymał dożywotnio Konrad Rudy, a po jego śmierci przejąłby je król, co odbyłoby się bez użycia siły i tym samym bez zniszczenia kraju, które przyniosłaby ze sobą wojna. Gdyby król zażądał jednak również udzielenia pomocy, nie można się od tego uchylić, ale należy powiązać tę kwestię z konfliktem Zakonu z biskupem warmińskim ${ }^{31}$

${ }^{28}$ O kancelarii wielkiego mistrza w Królewcu zob. ogólnie M. Th u m s e r, Schriftlichkeit, s. 168-178.

${ }^{29}$ OF $18 \mathrm{c}$, s. 108.

${ }^{30}$ Tamże.

31 Był nim wówczas Łukasz Watzenrode, który w 1493 r. popadł w ostry konflikt z Zakonem, właśnie w 1495 r. zgłaszając projekt przesiedlenia go na Podole w celu walki z Tatarami; planom tym werbalnego przynajmniej poparcia w Kurii udzielał Jan Olbracht - K. G ó r s k i, Łukasz Watzenrode. Życie i działalność polityczna (1447-1512), Wrocław 1973, s. 52-58; M. B i s k u p, Polska a Zakon Krzyżacki w Prusach w początkach XVI wieku. U źródeł sekularyzacji Prus Krzyżackich, Olsztyn 1983, s. 47-49. 
władca powinien w nim bronić Zakonu i przymusić hierarchę do przestrzegania warunków pokoju, w przeciwnym razie konflikt ten stanowiłby przeszkodę w krzyżackiej ekspedycji na Mazowsze ${ }^{32}$.

$\mathrm{Na}$ tych przedłożeniach bazowali reprezentanci stanów, których stanowisko 19 sierpnia przedstawił wielkiemu mistrzowi Both von Eulenburg ${ }^{33}$. Doradzał on wysłanie do Jana Olbrachta uroczystego poselstwa (,eyne merglich botschaft”), złożonego z dwóch dostojników Zakonu, którzy powinni prosić króla o możliwość udania się do księcia Konrada, aby podjąć się mediacji w jego sporze z Koroną i doprowadzić do zgody bez zniszczenia kraju. Gdyby jednak książę (tu w zakonnym sprawozdaniu omyłkowo wpisane imię Hans) nie chciał skorzystać z tej oferty, to wielki mistrz razem z dostojnikami powinien postąpić „,nach inhalt des ewigen fredes". Przewidziano również wariant, że to król odrzuci koncepcję zakonnego pośrednictwa i zechce sprawę rozstrzygnąć mieczem - wówczas stany ustami swego przedstawiciela doradzały zwierzchnikowi Zakonu, aby powołał się na panującą w kraju zarazę uniemożliwiającą zebranie odpowiednich sił. W ślad za ekspertyzą prawniczą sugerowano też $\mathrm{w}$ tej sytuacji, aby zaprotestować przeciwko posunięciom biskupa warmińskiego Łukasza Watzenrodego i zażądać od polskiego monarchy ochrony dla Zakonu przeciwko niemu ${ }^{34}$. Po udzieleniu rady ze strony stanów przerwano obrady do popołudnia, kiedy znowu zebrali się zarówno reprezentanci rycerstwa i miast, jak też prałaci i urzędnicy z rady wielkiego mistrza. Powtórzono wówczas złożone już wcześniej propozycje, dodając możliwość podjęcia się przez Zakon mediacji pomiędzy królem a Konradem, ,jedynym żyjącym księciem na Mazowszu"35. Stanowisko krzyżackie podsumowano w projekcie posłania (instrukcji dla posła?) skierowanego do króla, dając pierwszeństwo środkom pokojowym. Dużo uwagi poświęcono także konieczności załagodzenia sporu Zakonu z biskupem warmińskim; przywoływano tutaj stanowisko przedstawione już królowi niedawno, w końcu czerwca 1495 r., w Wiskitkach przez komtura pasłęckiego Szymona von Drahe ${ }^{36}$. Ostatecznie zaproponowano polskiemu monarsze, że najpierw wielki mistrz wyśle posłów do księcia Konrada, aby załagodzić sprawę, a gdy to nie poskutkuje, wywiąże się również czynnie ze swoich powinności ${ }^{37}$.

Był to jednak moment, kiedy krzyżacka pomoc okazała się już zbędna, ponieważ król 3 sierpnia był w Płocku, wkrótce potem zajął inne sporne ziemie, a Konrad Rudy zobowiązał się do złożenia mu hołdu lennego ${ }^{38}$. Opieszałe działanie wielkiego mistrza nie było kwestią przypadku. Władze w Królewcu śledziły bieg wydarzeń na Mazowszu i kiedy w kwietniu 1495 r. (zatem sporo przed przybyciem do Prus

${ }^{32}$ OF $18 \mathrm{c}$, s. 108.

33 Przedstawiciel łużyckiej rodziny od dawna związanej z Zakonem, a po wojnie trzynastoletniej osiadłej w Prusach, obecny w otoczeniu wielkiego mistrza - E. H o 11 a c k, Das Haus Eulenburg in Preussen und der Lausitz von 1400-1488, Königsberg i. Pr. 1916, s. 99; por. G. Ve r c a m e r, Siedlungs-, Sozial- und Verwaltungsgeschichte der Komturei Königsberg in Preußen (13.-16. Jahrhundert), Marburg 2010, według indeksu.

34 OF $18 \mathrm{c}$, s. 109.

35 Tamże, s. 109-110.

36 Tamże, s 111-112. O misji Szymona von Drahe zob. M. B i s k u p, Polska a Zakon, s. 49.

37 OF $18 \mathrm{c}, \mathrm{s} .113$.

${ }^{38}$ F. P a pé e, Jan Olbracht, s. 90-91; J. G r a b o w s k i, Dynastia, s. 190-191. 
Jana Konopackiego) do Inflant udawał się poseł Jana von Tiefena (jego kompan Werner von Drachenfels), w instrukcji dla niego wspominano, że po śmierci księcia Janusza, książę Konrad („noch im leben”) nie posiada żadnych dziedziców i król Polski zamierza sam objąć dziedzictwo mazowieckie, a ponieważ Zakon graniczy z tymi ziemiami, należy wobec tego utrzymywać w dobrym stanie graniczne zamki. Dalej wyrażona została obawa, że o ile „stary król” (Kazimierz Jagiellończyk) zabrał książętom Mazowsza prawie połowę kraju, to niewykluczone, że Jan Olbracht jeszcze za życia księcia Konrada, albo po jego śmierci, zagarnie całość ziem mazowieckich, a wówczas zakon w Prusach będzie ,mit synen landen gantcz umbringet”39. Informacja o braku dziedziców Konrada II wiosną 1495 r. była aktualna i precyzyjna, książę ten, prowadząc dość bogate życie osobiste (w przytoczonej wyżej instrukcji wspomniano, że „umbe seins unordentlichenn weszens swach und ungeacht ist”), zawarł małżeństwo z Anną Radziwiłłówną (dające mu nadzieję na legalne potomstwo) dopiero jesienią 1496 r., a synowie z niego narodzili się u progu następnego stulecia ${ }^{40}$. Niechęć Królewca wobec angażowania się w posunięcia wymierzone w książęce Mazowsze związana była też z faktem, że oba władztwa utrzymywały przyjazne stosunki, zwłaszcza po 1466 r., co wynikało zarówno ze współpracy gospodarczej, jak też (a może przede wszystkim) z poczucia wspólnoty politycznego losu' ${ }^{41}$.

Trudno przesądzić, czy Jan Olbracht, wysyłając posła do Prus Zakonnych, rzeczywiście liczył na podjęcie akcji zbrojnej przez wielkiego mistrza. Misja Konopackiego była późna, skoro rozpoczęcie akcji zbrojnej było planowane zaraz po 10 VIII $1495 \mathrm{r}$. Chodziło raczej i o przypomnienie Janowi von Tiefenowi jego zobowiązań wobec Korony, i o dodatkowy element nacisku psychologicznego na Konrada Rudego. Oba te cele udało się królowi osiągnąć - Krzyżacy poza graniem na zwłokę nie byli w stanie odrzucić jego żądań ani na płaszczyźnie prawnej, ani - co istotniejsze - w sferze realnej. Niespełna dwa lata później Jan von Tiefen na czele zakonnego kontyngentu wyruszył w pole, aby wypełnić swe powinności i wesprzeć Jana Olbrachta w jego wyprawie mołdawskiej, co pośrednio doprowadziło, jak wiadomo, do jego zgonu na dyzenterię we Lwowie ${ }^{42}$.

\section{BIBLIOGRAFIA}

Biskup M., Polska a Zakon Krzyżacki w Prusach w początkach XVI wieku. U źródeł sekularyzacji Prus Krzyżackich, Olsztyn 1983.

Biskup M., Trzynastoletnia wojna z Zakonem Krzyżackim 1454-1466, Warszawa 1967.

Dralle L., Der Staat des Deutschen Ordens in Preußen nach dem 2. Thorner Frieden, Wiesbaden 1975 .

${ }^{39}$ Liv-, Est- und Kurländisches Urkundenbuch, dział II, t. I, wyd. H. Hildebrand, Ph. Schwartz, L. Arbusow, Riga-Moskau 1900, nr 181, s. 137, 140.

40 Tamże, s. 140; J. G r a b o w s k i, Dynastia, s. 482-484, 506-507.

${ }^{41}$ Zagadnieniu temu zamierzam poświęcić osobną publikację. Przypomnijmy jedynie, że w 1477 r. mówiono o planach sojuszu krzyżacko-mazowieckiego przeciw Polsce - Joannis Dlugossii Annales seu cronicae incliti Regni Poloniae, lib. XII: 1462-1480, wyd. K. Baczkowski, K. Ożóg, K. Pirożyńska, Kraków 2005, s. 395; H. S a m s o n o w i c z, A. S u p r u n i u k, Dzieje polityczne (połowa XIV - początek XVI wieku), w: Dzieje Mazowsza, t. I, Pułtusk 2006, s. 316.

42 A. S z w e d a, Princeps, s. 257-258. 
Górski K., Łukasz Watzenrode. Życie i działalność polityczna (1447-1512), Wrocław 1973.

Grabowski J., Dynastia Piastów mazowieckich. Studia nad dziejami politycznymi Mazowsza, intytulacją i genealogią książąt, Kraków 2012.

Hollack E., Das Haus Eulenburg in Preussen und der Lausitz von 1400-1488, Königsberg i. Pr. 1916.

Jasiński K., Rodowód Piastów mazowieckich, Poznań-Wrocław 1998 [recte: 2008].

Jóźwiak S., Sposoby zaprzysięgania polsko-krzyżackich traktatów pokojowych w XV w. na tle zachodnioeuropejskich procedur ratyfikacyjnych, w: Toruń miastem pokoju. II pokój toruński, Toruń 2016.

Neitmann K., Von der Herstellung und Sicherung des „ewigen Friedes”. Der II. Thorner Friede von 1466 im Rahmen der Landfriedensvereibarungen und Friedenschlüsse des Deutschen Ordens in Preußen mit seinen Nachbarmächten im 15. Jahrhundert, w: Erbeinungen und Erbverbrüderungen in Spätmittelalter und Früher Neuzeit. Generationsübergreifende Verträge und Strategien im europäischen Vergleich, Berlin 2014.

Nowosad W., Konopaccy herbu Odwaga - dzieje pomorskiej rodziny senatorskiej w XV-XVIII wieku, Warszawa 2014.

Papée F., Jan Olbracht, Kraków 2006 (wyd. 1: 1936).

Samsonowicz H., Supruniuk A., Dzieje polityczne (połowa XIV - początek XVI wieku), w: Dzieje Mazowsza, t. I, Pułtusk 2006, s. 316.

Swieżawski A., Wcielenie ziemi rawskiej, gostynińskiej i bełskiej do Korony (1462), Zeszyty Naukowe UŁ, Nauki Humanistyczno-Społeczne, seria I, z. 27, 1962 (przedruk w: tenże, Mazowsze i Ruś Czerwona w średniowieczu. Wybór pism, Częstochowa 1997).

Szweda A., Princeps et consiliarius Regni Poloniae. Król i wielki mistrz w latach 1466-1497, w: Od traktatu kaliskiego do pokoju oliwskiego. Polsko-krzyżacko-pruskie stosunki dyplomatyczne w latach 1343-1660, Warszawa 2014.

Tęgowski J., Odłączenie ziemi płockiej od Mazowsza w latach 1495-1496 (przyczynek źródłowy), w: Stilo et animo. Prace historyczne ofiarowane Profesorowi Tomaszowi Jasińskiemu w 65. rocznicę urodzin, Poznań 2016.

Thumser M., Schriftlichkeit in der Spätzeit der preußischen Deutschordensherrschaft. Kanzleitätigkeit und Aufzeichnungen des hochmeisterlichen Sekretärs Liborius Naker (+1502/1503), w: Schriftkultur und Landesgeschichte. Studien zum südlichen Ostseeraum vom 12. bis zum 16. Jahrhundert, Köln-Weimar-Wien 1997.

Vercamer G., Siedlungs-, Sozial- und Verwaltungsgeschichte der Komturei Königsberg in Preußen (13.-16. Jahrhundert), Marburg 2010.

Węcowski P., Mazowsze w Koronie. Propaganda i legitymizacja władzy Kazimierza Jagiellończyka na Mazowszu, Kraków 2004.

\section{Bemühungen König Johann Albrechts von Polen um Hilfe des Deutschen Ordens gegen Herzog Konrad III. den Roten von Masowien im Jahre 1495}

\section{Zusammenfassung}

Nach dem Abschluß des Zweiten Thorner Friedens 1466 ist der Hochmeister des Deutschen Ordens „Fürst und Rat der Krone” geworden, der dazu verpflichtet war, dem polnischen König militärischen Beistand zu leisten. An diese Pflicht erinnerte König Johann Albrecht den Hochmeister Johann von Tiefen, als 1495 nach dem Tod des Herzogs Janusz II. von Masowien sein Brunder Konrad der Rote das Fürstentum Płock eingenommen hatte, auf das auch die Krone Ansprüche geltend machte. Johann Albrecht entsandte seinen Sekretär Johann Konopacki mit der Forderung nach Preußen, bewaffnete Hilfe gegen Konrad zu leisten. Die Ordensleitung unterstützte diese Aktion nicht, weil sie befürchtete, daß die Krone sich ganz Masowien einverleiben und die Stellung des Ordens somit noch mehr geschwächt würde. Der Hochmeister sah 
aber zusammen mit Vertretern der preußischen Stände keinen Ausweg, den Forderungen des Königs zu widerstehen (rechtlich gesehen hatte er keine Gründe, diese abzulehnen, er verfügte auch über keine reale Macht), weshalb er auf Zeit spielte. Er verschob seine Entscheidung bis zur Versammlung der Stände, dann bot er sich als Vermittler zwischen dem König und Herzog Konrad an. Auch versuchte er, die Angelegenheit mit seinem Streit mit dem Bischof von Ermland Lukas Watzenrode in Verbindung zu bringen Der König entschied den Streit mit Konrad dem Roten schließen ohne die Hilfe des Ordens zu seinen Gunsten. Zwei Jahre später nahm Johann von Tiefen am Kriegszug Johann Albrechts in die Moldau teil, wo er auch gefallen ist.

Übersetzt von Waldemar Könighaus

\title{
King Jan Olbracht's solicitation for help from the Teutonic Order against Konrad III the Red, duke of Masovia, in 1495
}

\begin{abstract}
The paper presents the activities of Jan Olbracht, who in 1495 requested help from the Grand Master of the Teutonic Order, Johann von Tiefen, against against Konrad III the Red, duke of Masovia, who illegally took over the Duchy of Płock after the death of his brother Janusz II. Faced with the demands presented by the royal envoy Jan Koniecpolski, the Order's authorities temporised with the king. A special state meeting was convened and the Order's mediation was suggested to the king, only after the fiasco of which, military aid was promised. The validity of king's request was not questioned, however. Eventually, the help of the Grand Master was not needed, because Jan Olbracht soon solved his argument with the Masovian duke.
\end{abstract}

Translated by Rafat T. Prinke

dr hab. Adam Szweda, prof. UMK, Instytut Historii i Archiwistyki, Uniwersytet Mikołaja Kopernika w Toruniu, ul. W. Bojarskiego 1, 87-100 Toruń, e-mail: aszweda@umk.pl 